\title{
COMPOSITION AND CHARACTERISTICS OF RED MUD: A CASE STUDY ON TAYAN BAUXITE RESIDUE FROM ALUMINA PROCESSING PLANT AT WEST KALIMANTAN
}

\author{
Komposisi dan Karakteristik Red Mud: Studi Kasus Residu Bauksit \\ Tayan Pabrik Pengolahan Alumina di Kalimantan Barat
}

\author{
RETNO DAMAYANTI and HERNI KHAERUNISSA \\ R\&D Centre for Mineral and Coal Technology \\ Jalan Jenderal Sudirman 623 Bandung 40211 \\ Phone. (+6222) 6030483 Ext. 404, Fax. (+6222) 6003373 \\ e-mail: retnod@tekmira.esdm.go.id
}

\begin{abstract}
Bauxite residue emerges as the major waste material during production of alumina from bauxite by the Bayer's process. An alumina refinery built in Tayan, West Kalimantan has a production capacity of 300 thousand tons per year. It means that it will produce red mud or bauxite residue approximately $300-$ 350 thousand tons per year and washing residue around 200 thousand tons per year. Right now, it is stored in a nearby disposal area. This paper focuses on the characteristic study of the bauxite residue to evaluate the potential pollution risk to the surrounding environment. This experimental-based study is conducted to get appraisal and description of the residue regarding its utilization. Some characterization tests were conducted in the laboratory to find the properties of bauxite residue coupled with the previous study. It is found from the study that bauxite residue shows radioactivity elements. It comprises of oxides of iron, titanium, aluminum and silica along with some other minor constituents in the form of heavy metals and rare earth elements. Hazardous elements such as $\mathrm{As}, \mathrm{Pb}, \mathrm{Cr}$ and $\mathrm{Hg}$ were found in bauxite residue samples. But, the toxicity test showed that bauxite residue samples were not classified as hazardous material. Some rare earth elements such as $\mathrm{Ga}, \mathrm{Ce}, \mathrm{Sc}, \mathrm{Pr}, \mathrm{Gd}$, Tb etc. were also detected in the samples.
\end{abstract}

Keywords: bauxite residue, red mud, Bayer process, alumina, heavy metals

\begin{abstract}
ABSTRAK
Residu bauksit terbentuk sebagai limbah utama produksi alumina yang berasal dari bauksit melalui proses Bayer. Pemurnian alumina yang dibangun di Kalimantan Barat memiliki kapasitas produksi 300 ribu ton per tahun. Hal ini berarti akan dihasilkan residu bauksit kurang lebih 300-350 ribu ton per tahun dan residu proses pencucian sekitar 200 ribu ton per tahun. Pada saat ini, residu tersebut disimpan di daerah pembuangan terdekat. Makalah ini difokuskan pada komposisi dan karakteristik residu bauksit untuk mengevaluasi risiko pencemaran potensial terhadap lingkungan sekitarnya secara umum. Penelitian berdasarkan hasil percobaan ini dilakukan untuk memberikan penilaian dan gambaran pemanfaatannya. Beberapa tes karakterisasi dilakukan di laboratorium untuk menemukan sifat-sifat residu bauksit dan digabungkan dengan hasil penelitian sebelumnya. Berdasarkan studi yang dilakukan, residu bauksit terdeteksi mengandung unsur-unsur radioaktif. Bahan ini juga terdiri atas oksida besi, titanium, aluminium dan silika bersama dengan beberapa konstituen minor lainnya dalam bentuk logam berat dan unsur tanah jarang. Unsur-unsur berbahaya seperti $\mathrm{As}, \mathrm{Pb}, \mathrm{Cr}$ dan $\mathrm{Hg}$ ditemukan pula dalam percontoh residu bauksit. Namun demikian, uji toksisitas menunjukkan bahwa percontoh residu bauksit tersebut tidak diklasifikasikan sebagai bahan berbahaya. Beberapa unsur tanah jarang seperti Ga, Ce, Sc, Pr, Gd, Tb dll, juga terdeteksi ada dalam percontoh.
\end{abstract}

Kata Kunci: residu bauksit, lumpur merah, proses Bayer, alumina, logam berat 


\section{INTRODUCTION}

The estimation of the world bauxite resources is about 55 to 75 billion tons. Those are $32 \%$ in Africa, $23 \%$ in Oceania, $21 \%$ in South America and the Caribbean, $18 \%$ in Asia and 6\% elsewhere (Patel and Pal, 2015). Nearly $90 \%$ of the world bauxite reserves are concentrated in tropical and sub-tropical regions flat layers lying near the surface and may cover many miles with the average thickness of $4-6$ meters. The estimated reserves of the world bauxite in all categories are around 28 billion tons. World distribution of bauxite production and reserves have been revised based on new information available through Government reports and other sources. Bauxite ore is mined on a large scale in most countries in the world. For example in Australia, which is the world's largest bauxite producer ( 40\%) with a current annual production of about 55 million tones. The main deposits of bauxite in Australia are in the north-western region of Western Australia. Bauxite is refined to produce alumina (anhydrous aluminium oxide) at refineries in Western Australia and Queensland. The current annual production of alumina in Australia is approximately 16 million tons. Most of the production ( $80 \%)$ is exported. The remainder of the alumina is smelted at plants in several Australian states to produce aluminium ingots for fabrication into a range of industrial and domestic products. Approximately 1.8 million tons of ingots are produced locally (Cooper, 2005). In 2003 , the amount of bauxite residue reported in Australia was 26 million tons (dry basis). The terminology of bauxite residue will be often used because the environmental connotation of this by product is still positive if the producer can process it in an efficient way. It is estimated that there is an annual generation in excess of 26 million tons of bauxite residue and other solid waste from alumina production in Australia. Disposal of bauxite residue and other solid residues commonly takes place by spreading in layers over a large area to allow the material to dry, followed by rehabilitation of the land, which involves the waste with sand and revegetating the surface.

The global bauxite production decreased by $17 \%$ from the 2013 production. It is mostly caused by the low production in Indonesia. In response to a Government ban on exporting bauxite and other unprocessed mineral ores that took effect on January 12 , 2014, bauxite mines throughout Indonesia was shut down and production decreased from 55.7 million tons in 2013 to an estimated 500,000 tons in 2014 . The ban was part of a mining law that was instituted in 2009 to increase development of downstream processing facilities in Indonesia (Bray, 2015).

Based on its chemical composition, there are three main structural types of bauxite. These are (Gow and Lozej, 1993):

- gibbsite, $\mathrm{Al}_{2} \mathrm{O}_{3} \cdot 3 \mathrm{H}_{2} \mathrm{O}$;

- boehmite, $\mathrm{Al}_{2} \mathrm{O}_{3} \cdot \mathrm{H}_{2} \mathrm{O}$;

- diaspore, $\mathrm{Al}_{2} \mathrm{O}_{3} \cdot \mathrm{H}_{2} \mathrm{O}$.

Each type has different characteristics that make them more or less desirable for mining and metallurgical purposes. In the previous part it has been mentioned that the main mineral source of aluminium is bauxite, which contains 30 to $50 \%$ hydrated aluminium oxide. As a light weight, high strength and recyclable structural metal, aluminium have an important role in all living activities such as infrastructure, building and construction, transportation, beverage, electronic and electrification, aerospace and defense etc. (Rai et al., 2012). The aluminium production consists of three stages process like mining the bauxite, refining the alumina from the bauxite (Bayer process) and smelting the alumina to be the aluminium (Hall Heroult process). There are five basic steps in the bauxite refinery process, which is termed as the Bayer process (Cooper, 2005). Those are:

- bauxite washing and grinding;

- bauxite digestion in caustic soda at high temperature and pressure;.

- separation and washing of solid residues;

- crystallization of hydrated alumina;

- calcining at about $1000^{\circ} \mathrm{C}$ to remove water and produce anhydrous alumina.

The other main raw materials for this process, a part from bauxite, are caustic soda and lime.

To produce the aluminium metal, it will involve electrolysis of the alumina. This happens in a mixture of fluoride salts, in carbon cells container. The electrolysis takes place at around $970{ }^{\circ} \mathrm{C}$ and the aluminium is removed from the production cells as the molten metal, allowed to solidify 
and casted as ingots. Other aluminium products for special applications, such as powder sand pastes, are produced from the molten metal (Cooper, 2005).

Bauxite residue or red mud is an insoluble by product of aluminium production using Bayer process. The main insoluble solid residues or the undissolved bauxite residues mostly contain iron, silica and titanium which removed from the digestion step of the process. These residues are produced in large quantities. The volume of red mud generated in the alumina processing plant depends on the quality or grade of crude bauxite. One ton of produced aluminium generates 2 tons of waste and nowadays, it is estimated that during bauxite processing, 120 million tons of red mud is produced worldwide (Schwarz and Lalk, 2012). The bauxite waste slurry from the processing of bauxite through a Bayer process contains about $15-40 \%$ solids and retains high alkaline performed by $\mathrm{pH}$ of $12.5(\mathrm{Li}, 1998$; Ranveer, 2015). Patel and Pal (2015) stated the amount of the red mud generated per ton from the alumina processed varies greatly with the type of the bauxite ore used from 0.3 ton to 2.5 tons for high and very low grade bauxites respectively. The red mud is usually discharged into storage impoundments where the solids settle and consolidate as well as the alkaline water at the top is removed. The main liquid waste arises from the washing of solid waste and the settling ponds and also leachates from the disposal areas are recycled, collected and returned to production and as the process water.

The general chemical composition data of the bauxite may consist of the wide ranges of constituents such as $\mathrm{Fe}_{2} \mathrm{O}_{3} 30-60 \%$, $\mathrm{Al}_{2} \mathrm{O}_{3} 10-20 \%, \mathrm{SiO}_{2} 3-50 \%, \quad \mathrm{Na}_{2} \mathrm{O} 2-10 \%$, $\mathrm{CaO}-8 \%$, and $\mathrm{TiO}_{2}$ trace to $10 \%$ (Cablik, 2007). Sometimes the red mud has a high content of valuable metal elements such as $\mathrm{V}, \mathrm{Ga}$ and also radioactive elements. There is a wide range of metallic oxides present at low levels in the bauxite residues; they include the oxides of calcium, chromium, magnesium, manganese, vanadium, zinc and zirconium.

In addition, trace quantities of barium, cadmium, mercury, and nickel can sometimes be found depending on the source of the original bauxite. Considering the low concentrations involved, acute adverse health effects from heavy metal exposure are unlikely to occur. The exact composition of the red mud stored in impoundments will be known only after the results of the chemical analysis will be made available.

\section{Radioactivity}

The original bauxite ores can contain significant levels of natural radioactivity due to both uranium $\left({ }^{238} \mathrm{U}\right)$ and thorium $\left({ }^{232} \mathrm{Th}\right)$ and respective decay products. Some of the radioactivity may be associated with trace quantities of other minerals, such as ilmenite or monazite. Levels of ${ }^{238} \mathrm{U}$ and ${ }^{232} \mathrm{Th}$ can range from $120-350 \mathrm{~Bq} / \mathrm{kg}$ and $450-$ $1000 \mathrm{~Bq} / \mathrm{kg}$, respectively, depending on the source of the bauxite ore. Virtually the entire amount of radioactivity is transferred to the solid waste, and little, if none, of the uranium or thorium is present in the alumina. Moreover, there is a three-fold increase in the radionuclide content of red mud compared to the original bauxite mineral. The concentrations of natural radio nuclides in red mud from Western Australian sources had been reported and the values can be compared with the natural background concentrations of $20-110 \mathrm{Bg} / \mathrm{kg}$ for uranium and $50-500 \mathrm{~Bq} / \mathrm{kg}$ for thorium in gravel soils in the region of Western Australia where the bauxite mining takes place (Grafe et al., 2010).

Red mud has also radioactive elements with low radioactivity. First, it must be established the term of the "Natural Radioactivity" which actually means and where the boundary between nuclear and non-nuclear industry is. There is no difference between radiation dose of $3 \mathrm{mSv}$ received by an uranium miner and a dose of $3 \mathrm{mSv}$ for an operator of a tin smelter. The argument that in the case of uranium mining, radiation is beneficial for the product and in other mining, radiation is an unwanted impurity. Those perspectives, from the general radiation protection point of view, are irrelevant outlook. Uranium is the same 'naturally occurring radioactive material', with a concentration being technically enhanced. Further, the uranium processing chain one may argue that metallic enriched uranium is the same natural substance with the concentration of ${ }^{235} U$ technically enhanced. Since the 
radioactive content is in no way beneficial for the depleted uranium, its use, also could not be classified as a 'nuclear-related activity', yet. It looks like that the 'real' boundary between 'natural radio activities' and 'nuclear activities' is reached when the uranium is already in the form of fuel rods inside the reactor. The next stages of producing isotopes especially ones that are not found in nature (Technecium-99, for example) could be already named as 'nuclear activities'. Linear accelerators, use of radioisotopes in nuclear medicine, industrial use of X-ray equipment, and radiochemistry of isotopes definitely could not also be classified as dealing with 'natural radioactivity' (Tsurikov, 1999).

Bauxite is a naturally-occurring and one of the most abundant materials in the Earth crust. It is practically found everywhere on earth, though higher grade bauxite is traditionally found in some regions. Some of the bauxites contain very low levels of radioactive species, on a par with naturally occurring radioactivity found in granite rocks in various regions of Europe. The concentrations of naturally occurring radioactive materials such as uranium and thorium are very low in bauxite residues and are not expected to cause any adverse health effects.

Some bauxite residues or red mud may emit ionizing radiation above natural background rates due to the presence of naturally occurring radioactive materials (NORMs). The NORM is a term used to describe radionuclide containing materials that exist in the natural environment. Long-lived radioactive elements of interest include uranium, thorium and potassium, and any of their radioactive decay products, such as radium and radon. These elements have always been present in the earth's crust and within the tissues of all living species. The radioactive materials which generally occur naturally are ${ }^{238} \mathrm{U}$ and/or ${ }^{228,} 230,{ }^{232} \mathrm{Th}$ and their decay chains (Evans, 2015).

European Community Radioactivity Protection Committee has limited the radioactivity of ${ }^{232} \mathrm{Th}$ on $1000 \mathrm{~Bq} / \mathrm{kg}$. The threshold value for construction building in Europe should not exceed 1 (near the worker) $\mathrm{Bq} / \mathrm{kg}$. It must be considered because ionizing radiation will interact with the atoms and molecules make up the cells of a living organism and alter them chemically. Indonesia has such a regulation from the Head of Agency of Nuclear Energy Supervision No. 9/2009 about Intervention of Exposure from Technologically Enhanced Naturally Occurring Radioactive Material (Head of Agency of Nuclear Energy Supervision, 2009)and No. 16/2013 about Radiation Safety on the Safekeeping or Storage of the Technologically Enhanced Naturally Occurring Radioactive Material (Head of Agency of Nuclear Energy Supervision, 2013).

\section{Rare Earth Elements}

Red mud as the waste product of Bayer Process represents a potential secondary resource of rare earth elements (REE). The REE found in the red mud generally are Sc, Y, La, Ce, Pr, Nd, Sm, Eu, Gd, Tb, Dy, Ho, $\mathrm{Er}, \mathrm{Tm}, \mathrm{Yb}$, and $\mathrm{Lu}$. It depends on the geological bauxite origin. The REE-bearing materials pass through the Bayer Process and are concentrated in red mud. The red mud produced from alumina processing contain a potentially important concentration of REE because it has been demonstrated that the REE pass through the alumina extraction process into the waste. The total REE concentrations will be improved twice compared to the original material compared with the original bauxite ore. It is found consistently in Jamaican, Greek and Turkish deposits. In Greece and Turkey, the red mud contains 900 ppm REE in average. It is higher than those in bauxite ore which has typical values of $<100$ ppm to nearly 500 ppm. Extraction of REE from red mud has been predicted to be feasible. It would be challenging due to its heterogeneous spatial distribution of REE in the primary bauxite deposits, an unclear understanding of the REE mobility in red mud tailings ponds, and the need for developing the appropriate processing methods (Deady et al., 2015).

The resource potential of red muds in Europe (including Turkey) is significant with approximately 3.5 millions tons of bauxite extracted in 2012, which produced an estimated 1.4 million tons of red mud (Deady et al., 2014). Also, millions of tons of red mud are currently stockpiled in onshore Europe storage facilities. Those represent a potential REE resource with the average total nearly 1000 ppm (Deady et al., 2016). 


\section{Environmental Impacts}

In 2011, Indonesia exports accounted for $49 \%$ of global bauxite exports (Kuo, 2015). From PT. Antam internal research the Indonesian bauxite resource reached about 230 million tons and mainly located in West Kalimantan and Riau. All of that crude bauxite $(100 \%$ or 27.41 million tons) had been exported till 2011 (Miraza, 2011). After the implementation of Law No. 4/2009, due to the ore export restriction, the enterprises should establish domestic alumina refineries and an aluminum smelter.

From the environmental point of view, red mud is characterized by:

- its high alkalinity due to sodium hydroxide $(\mathrm{NaOH})$ addition;

- its high metal concentrations mostly comes from iron oxide $\left(\mathrm{Fe}_{2} \mathrm{O}_{3}\right)$ and aluminium oxide $\left(\mathrm{Al}_{2} \mathrm{O}_{3}\right.$;

- its high electrical conductivity.

However, the composition and properties of red mud are very different since the difference bauxite origin and its utilizing the technology of alumina processing plants.

Environmental impacts that might occur near red mud impoundments/disposal include (Patel and Pal, 2015):

- risk for all living organism due to high $\mathrm{pH}$ solid waste/slurry;

- leakage of alkaline leachate into the groundwater;

- problem caused by storage and maintenance that must consider its safety and cost;

- erosion of red mud and discharge into nearby surface waters;

- air pollution due to the generation of red mud dust as alkaline airborne dust.

Direct contact with a living organism will result in the immediate and severe tissue damage by denaturing proteins in the tissue.

To prevent the hazardous impact of alumina processing solid waste utilization, red mud environmental properties is very important to investigate from the beginning. The investigation should include toxicity, radioactivity and corrosivity (Dobra et al., 2015).
As the fifth country in Asia Pacific region which developed alumina processing plant, Tayan Alumina Processing plant, West Kalimantan, Indonesia is a new alumina production plant built in 2014. This plant uses a local bauxite from surrounding mine and produces about 300 thousands or 0.3 million tons per year of chemical grade alumina by Bayer process. Another processing plant had also been developed at Ketapang, West Kalimantan to produce a smelter grade alumina with the total capacity of 1.2 million tons alumina per year. Some reports have been published about the mineral characterization of Tayan red mud from West Kalimantan, Indonesia. It is essential to know the basic chemical and mineral composition of red mud for its environmental assessment and its comprehensive use in industrial applications.

A report about the mineral characterization of Tayan bauxite residue from West Kalimantan, Indonesia has been published. It is essential to know the basic chemical and mineral composition of bauxite residue for its environmental assessment and its comprehensive use in industrial applications. If both products are on schedule, it means that every year these plants require at least 3.42 million tons bauxite. Based on the existing reserves, these plants are expected lasting more than 100 years (Suseno, 2010). The general major elements composition of West Kalimantan bauxite are $\mathrm{Fe}_{2} \mathrm{O}_{3}(\sim 15.21$ $\%), \mathrm{Al}_{2} \mathrm{O}_{3}(\sim 50.9 \%)$ and $\mathrm{SiO}_{2}(\sim 1.17 \%)$ (Amalia and Aziz, 2011), but the composition of major elements in its residue are $\mathrm{Fe}_{2} \mathrm{O}_{3}$ ( 36.70\%), $\mathrm{Al}_{2} \mathrm{O}_{3}(\sim 26.10 \%), \mathrm{TiO}_{2}(\sim 2.04 \%)$, $\mathrm{SiO}_{2}(\sim 1.23 \%), \mathrm{Na}_{2} \mathrm{O}(\sim 2.30 \%)$ and $\mathrm{CaO}$ ( $0.117 \%)$ (Aziz, 2012). The objective of this study is to characterize Tayan bauxite residue, in terms of providing necessary data and a scientific basis for its comprehensive use to review the environmental impact of the alumina processing plant (Utasi et al., 2014). To have the bauxite residue baseline condition, research on material composition and properties of bauxite residue from Tayan Alumina Processing plant will be the main objective of the RDCMCT project namely "Processing and Utilization of Bauxite Residue for Soil Conditioner on Peatlands and Acid Mine Drainage Neutralizer". By combining few years' laboratory data and literature survey, the environmental issue and its assessment could be identified from the beginning. 


\section{METHODOLOGY}

\section{Materials}

The Tayan Alumina Processing plant at West Kalimantan produces bauxite residue that is started as a slurry and then forms large hard agglomerates when dried. Before starting the experiments, the bauxite residue was collected from the storage impoundment in May, 2015. After homogenizing process, the samples were dried at $105^{\circ} \mathrm{C}$ for 24 hours, then ground and milled into powders below $74 \mu \mathrm{m}$.

\section{Mineral Composition Analysis}

The mineral composition of the bauxite residue has been determined at the Testing Laboratory of the RDCMCT by XRD testing. The used X-ray machine was Rontgen diffractometer type XRD-700 Maxima-X from Shimadzu with the radiation source of copper capacity $2.7 \mathrm{~kW}$ and detector model Sc-1003. Its measurement capacity of $2 \Phi$ started from $3-130$ degrees.

\section{Chemical Composition Analysis}

Bauxite residue samples were dissolved by fusing aqua regia mixture. The solutions obtained were used to determine the percent of the oxides and heavy metals, specifically for:

- $\mathrm{SiO}_{2}$, LOI and $\mathrm{H}_{2} \mathrm{O}^{-}$by gravimetric analysis;

- $\mathrm{TiO}_{2}$ by spectrophotometric analysis;

- $\mathrm{Al}_{2} \mathrm{O}_{3}, \mathrm{Na}_{2} \mathrm{O}, \mathrm{K}_{2} \mathrm{O}, \mathrm{MgO}, \mathrm{CaO}$ and heavy metals by atomic adsorption spectrophotometer analysis;

- Total $\mathrm{Fe}$ and $\mathrm{FeO}$ by volumetric analysis and $\mathrm{Fe}_{2} \mathrm{O}_{3}$ based on the difference between $\mathrm{Fe}$ and $\mathrm{FeO}$;

- Trace elements by inductively couples plasma in the Laboratory of Center for Geological Resources.

\section{Heavy Metal Determination}

The leaching test has been conducted by the US EPA Method No. 1311 which is named as the toxicity characteristic leaching procedure (TCLP). The TCLP is designed to determine the mobility of both organic and inorganic analytes present in liquid, solid, and multiphasic wastes. The analysis was performed at MTRDC Testing Laboratory Bandung.

\section{Radioactive Element Determination}

Radioactive elements have been analyzed by Gamma spectrum method to determine the specific activity $(\mathrm{Bq} / \mathrm{kg})$ of the radioactive isotopes and the content of $\mathrm{U}, \mathrm{Th}$, and $\mathrm{K}$ in the samples. The radioactive activity was determined by total absorption peak of intensity gamma line for $\mathrm{Pb}-210$; Ra-226; Ra-228; U-238; Th-230; Th-234 and K-40. The analysis was performed at BATAN Laboratory - Jakarta.

\section{RESULTS AND DISCUSSION}

As a very fine material, bauxite residue has the average particle size below $10 \mu \mathrm{m}$. bauxite residue from the Bayer Process generally has high amount (65\%) fine particles $(0.01-0.005 \mathrm{~mm})$. Based on Aziz study in 2014, Indonesian bauxite residue from Tayan processing plant was dominantly composed by the fine particle fraction of -60 mesh performing quantity of about 31\%. Scanning Electron Microscopic analyses showed a hematite plate texture. The fine particles are categorized as polycrystalline and amorphous (Tsamo et al., 2014). The slurry of bauxite residue has high $\mathrm{pH}$ of about 10.72 , so it is classified as the alkaline material (Tóth et al., 2014).

The Indonesian bauxite residue dominantly consisted of hematite, goethite, gibbsite, carbonate-nosean, quartz, calcite and corundum. Calcite was the new form in this alumina process. Another mineral such as magnetite, ilmenite and titanite existed in a minor number. Titanite or $\mathrm{CaTiSiO}_{5}$. is a kind of calcium titanium nesosilicate mineral that occurs as a common accessory mineral in many igneous rocks. Trace impurities of iron and aluminum are typically present in titanite. Table 1 shows the mineral composition of bauxite residue. The difference composition is predicted due to its geological formation but in the certain area the difference is insignificant. From the mineralogical data, gibbsite is identified but it is not prominent as hematite and goethite. The Indonesian bauxite residue sample for this experiment might not be predicted as the gibbsitic bauxite.

$\mathrm{TiO}_{2}$ is fused in the phase of ilmenite and titanite in this bauxite residue. There is two dominant mass composition shown in the 
bauxite residue. All samples are in the iron bearing compounds such as goethite aluminian and hematite aluminian. Both are very stable from a chemical point of view, and naturally will pass unconverted into the bauxite residue. Both ilmenite and titanite bear the important amounts of irrecoverable $\mathrm{Al}_{2} \mathrm{O}_{3}$. In other countries, both materials also contain unusual large concentrations of amorphous unidentified compounds of alumina.

The concentrations of the major elements in the form of oxides in Indonesian bauxite residue are given in Table 2. Iron oxides are the major oxide in the bauxite residue followed by gibbsite-alumina (Table 1), silica, sodium, calcium and titanium oxides. The following major and minor elements were identified by combined analysis such as volumetric, gravimetric and spectrophotometric analysis. The elemental composition of Indonesian bauxite residue varies depending on the process conditions. The X-ray fluoresence (XRF) was introduced for comparing the result only.

Sodium in bauxite residue presents in the free soda form and bound soda form. The free sodium is in the form of $\mathrm{NaOH}, \mathrm{Na}_{2} \mathrm{CO}_{3}$, $\mathrm{NaAlO}_{2}$ etc. coming from the caustic soda which entrained in the bauxite residue slurry. It remains in the bauxite residue even though it was washed many times. The bauxite residue bound soda exists in the form of sodalite complex phase such as $3\left(\mathrm{Na}_{2} \mathrm{OAl}_{2} \mathrm{O}_{3} 2 \mathrm{SiO}_{2}\right) \mathrm{Na}_{2} \mathrm{X}$, where the $\mathrm{X}=$ $\mathrm{CO}_{2}^{2-}, 2 \mathrm{OH}^{-}, \mathrm{SO}_{4}^{2-}, 2 \mathrm{Cl}^{-}$(Patel and Pal, 2015).
In this case, the bound soda, $\mathrm{Na}_{8} \mathrm{Al}_{6} \mathrm{Si}_{6}\left(\mathrm{CO}_{3}\right) \mathrm{O}_{24}$ form, is predicted coming from the desilication step that is carried out during the Bayer process for removing the kaolinitic silica in the bauxite. Theoretically, bauxite residue is very fine materials with average particle size distribution of less than $10 \mu \mathrm{m}$ and has a high solid concentration of about $30-60 \%$. Due to this physical property, the bauxite residue disposal will face an environmental problem that has been mentioned above.

As the rule of thumb, every ton of dry red mud will be accompanied by up to 2 tons of liquor with a significant alkalinity of 5-20 g/L of caustic soda $\left(\mathrm{Na}_{2} \mathrm{CO}_{3}\right)$. Tayan Bayer bauxite residue consists mainly of $\mathrm{Fe}_{2} \mathrm{O}_{3}$, $\mathrm{Al}_{2} \mathrm{O}_{3}, \mathrm{SiO}_{2}, \mathrm{Na}_{2} \mathrm{O}, \mathrm{CaO}, \mathrm{TiO}_{2}, \mathrm{~K}_{2} \mathrm{O}$ and $\mathrm{MgO}$. It had a lower concentration in $\mathrm{CaO}$, $\mathrm{TiO}_{2}$, and $\mathrm{Fe}_{2} \mathrm{O}_{3}$ than those from other countries, but it had higher $\mathrm{Al}_{2} \mathrm{O}_{3}, \mathrm{SiO}_{2}$, and $\mathrm{Na}_{2} \mathrm{O}$ concentrations (Table 2). The differences in the average constituents maybe attributed to the variations of bauxite ores and the specific processing conditions, such as temperature, pressure etc. The Indonesian bauxite samples, including those from West Kalimantan province, could not be classified as gibbsite bauxite, because it dominantly contains hematite and goethite. According to Gu, Wang and Liu (2012), only bauxite residue with a high iron content (usually $\mathrm{Fe}_{2} \mathrm{O}_{3}>30 \%$ ) can be processed by reduction to recover iron; therefore, the highiron oxides in Tayan bauxite residue $(\sim$ $33.55 \%$ ) make it possible to recover iron under present technological constraints.

Table 1. Mineralogy composition of Indonesian bauxite residue

\begin{tabular}{clrr}
\hline No & \multicolumn{1}{c}{ Parameter in \%-wt } & Sample RMA-1 & Sample RMA-2 \\
\hline 1. & Hematite, aluminian $\left(\mathrm{FeO} .86 \mathrm{Al}_{0.14}\right)_{2} \mathrm{O}_{3}$ & 20.4 & 21.1 \\
2. & Goethite, aluminian $\mathrm{FeO} .83 \mathrm{Al}_{0.17} \mathrm{O}(\mathrm{OH})$ & 15.3 & 19.2 \\
3. & Gibbsite $\mathrm{Al}_{2} \mathrm{O}_{3} .3 \mathrm{H}_{2} \mathrm{O}$ & 14.1 & 12.9 \\
4. & Carbonate-nosean $\mathrm{Na}_{8} \mathrm{Al}_{6} \mathrm{Si}_{6}\left(\mathrm{CO}_{3}\right) \mathrm{O}_{24}$ & 13.25 & 13.2 \\
5. & Quartz $\mathrm{SiO}_{2}$ & 13.5 & 5.5 \\
6. & Calcite $\mathrm{CaCO}_{3}$ & 12.85 & 6.2 \\
7. & Corundum $\mathrm{Al}_{2} \mathrm{O}_{3}$ & 2.2 & 12.5 \\
8. & Magnetite $\mathrm{Fe}_{3} \mathrm{O}_{4}$ & 3.15 & 3.3 \\
9. & Ilmenite $\mathrm{FeTiO}_{3}$ & 3.15 & 3.6 \\
10. & Titanite CaTiSiO & 2.15 & 2.5 \\
\hline
\end{tabular}


Table 2. Major chemical component in the Indonesian bauxite residue

\begin{tabular}{|c|c|c|c|}
\hline \multirow[b]{2}{*}{ No } & \multirow{2}{*}{$\begin{array}{l}\text { Parameter in } \\
\text { percentage }\end{array}$} & \multicolumn{2}{|c|}{ Wet Analysis } \\
\hline & & $\begin{array}{l}\text { Sample } \\
\text { RMA-1 }\end{array}$ & $\begin{array}{l}\text { Sample } \\
\text { RMA-2 }\end{array}$ \\
\hline 1. & Fe Total & - & 27.80 \\
\hline 2. & $\mathrm{FeO}$ & 1.08 & 1.12 \\
\hline 3. & $\mathrm{Fe}_{2} \mathrm{O}_{3}$ & 28.6 & 38.50 \\
\hline 4. & $\mathrm{Al}_{2} \mathrm{O}_{3}$ & 23.3 & 19.22 \\
\hline 5. & $\mathrm{SiO}_{2}$ & 16.88 & 14.70 \\
\hline 6. & $\mathrm{Na}_{2} \mathrm{O}$ & 6.78 & 7.54 \\
\hline 7. & $\mathrm{CaO}$ & 5.43 & 2.61 \\
\hline 8. & $\mathrm{TiO}_{2}$ & 1.96 & 2.52 \\
\hline 9. & $\mathrm{~K}_{2} \mathrm{O}$ & 0.12 & 0.30 \\
\hline 10. & $\mathrm{MgO}$ & 0.24 & 0.37 \\
\hline 11. & LOI & 15.12 & 12.36 \\
\hline 12. & $\mathrm{H}_{2} \mathrm{O}^{-}$ & 24 & 1.50 \\
\hline
\end{tabular}

According to the analysis result, Tayan bauxite residue contains the REE such as $\mathrm{Ga}, \mathrm{Ce}, \mathrm{Sc}, \mathrm{Pr}, \mathrm{Gd}, \mathrm{Tb}$ and etc. These trace impurities are generally found in titanite or ilmenite (Gu, Wang and Liu, 2012). These are given in Table 3.

Due to its general characteristic as the hazardous material, bauxite residue must be considered to reuse as the secondary raw material. Also, since the scarcity of many natural resources, some of the REE's and the lanthanide elements in the bauxite residue can be potential resources if its extraction can be made economically acceptable.

The chemical analysis showed that the bauxite residue contains iron, aluminum, silicon, sodium, calcium, titanium as well as the minor elements such as $\mathrm{Cr}, \mathrm{Ba}, \mathrm{Cu}, \mathrm{Zn}$, $\mathrm{Ag}, \mathrm{As}, \mathrm{Hg}$, Se etc. $\mathrm{Pb}$ and $\mathrm{Cd}$ that exist below the detection limit of equipment for measuring these metals. The metal elements are characterized as the trace metals due to its concentration is less than $100 \mathrm{ppm}$. Heavy metals generally have a high adsorption affinity at the surface of the red mud oxide compounds (Palmer, Frost and Nguyen, 2009).

Concerning the environmental impact of these trace heavy metals, testing on the leaching test was also conducted in this project. The results of heavy metals analyses and its leaching were given in Table 4
Based on the TCLP test from the US EPA test method 1311, it will take a look the toxic characteristics of some element such as $\mathrm{Cr}$, $\mathrm{Ba}, \mathrm{Cu}, \mathrm{Zn}, \mathrm{Ag}, \mathrm{As}, \mathrm{Hg}, \mathrm{Se}, \mathrm{Pb}$ and $\mathrm{Cd}$. In the bauxite residue itself, $\mathrm{Cr}$ has a high concentration (36.6 - $42.4 \mathrm{ppm})$, but the leaching test showed that all toxic elements were in low concentration or not detected. It means that the Tayan bauxite residue is classified as the non-hazardous material. It is predicted that the heavy metals were a residual phase of the bauxite residue. However, the metal concentration and leachable metals seem to vary from some part in the impoundment area depends on the mineral origins, its occurrence and its amounts of toxic metals contained.

However, for environmental evaluation, it should be also considered its radionuclide activity content. Most bauxites will contain low levels of radioactive elements which termed as naturally occurring radioactivity material (NORM). The radioactivity in the red mud or bauxite residue is referred to as technologically enhanced naturally occurring radioactivity material (TENORM). In this case the radioactivity of Indonesian bauxite residue is shown in Table 5. The changes in the radionuclides activity, formed after introducing such technology, do not seem highly significant.

The International Atomic Energy Authority (IAEA) Basic Safety Guide for marketable materials sets a limit of $1 \mathrm{~Bq} / \mathrm{g}$ per radionuclide and the EU Radiation Protection Guideline 112 has a recommended radiation dose that ranges from $0.3-1 \mathrm{mSv} / \mathrm{y}$ for the building materials; the particular limit is being determined by the expected exposure (Evans, 2015). The results in Table 5 showed that the bauxite residue samples were not artificial radioactive isotopes such as ${ }^{137} \mathrm{Cs}$ or ${ }^{7} \mathrm{Be}$ (Hai et al., 2014).

One of the bauxite residue environmental property investigations is based on its radioactivity. This paper also takes a look on the radioactivity (only for the radionuclide of $\mathrm{U}, \mathrm{Pb}, \mathrm{Ra}, \mathrm{Th}$ and $\mathrm{K})$. A case study of Egypt bauxite residue, mentioned that almost all residue samples retained the low radioactivity compared to its raw material (Ibrahiem et al., 1999). 
Table 3. Concentration of REE in the Indonesian bauxite residue by ICP methods

\begin{tabular}{rrrr}
\hline No & Parameter in ppm & Sample RMA-1 & Sample RMA-2 \\
\hline 1. & $\mathrm{Ga}$ & 114.00 & 104.00 \\
2. & $\mathrm{Ce}$ & 62.30 & 54.86 \\
3. & $\mathrm{Sc}$ & 46.08 & 33.73 \\
4. & $\mathrm{Pr}$ & 38.05 & 12.74 \\
5. & $\mathrm{Gd}$ & 32.91 & 25.59 \\
6. & $\mathrm{~Tb}$ & 11.16 & 9.54 \\
7. & $\mathrm{Lu}$ & 7.34 & 5.53 \\
8. & $\mathrm{La}$ & 6.98 & 5.74 \\
9. & $\mathrm{Sm}$ & 5.50 & 3.52 \\
10. & $\mathrm{Nd}$ & 5.08 & 3.27 \\
11. & $\mathrm{Y}$ & 3.33 & 2.46 \\
12. & $\mathrm{Yb}$ & 3.99 & 3.01 \\
13. & $\mathrm{Eu}$ & 1.92 & 1.35 \\
14. & $\mathrm{Ho}$ & 0.00 & 0.00 \\
15. & $\mathrm{Tm}$ & 0.00 & 0.00 \\
16. & $\mathrm{Ta}$ & 23.04 & 0.00 \\
17. & $\mathrm{Dy}$ & 0.31 & 0.19 \\
\hline
\end{tabular}

Table 4. The heavy metals composition in Indonesian bauxite residue and its leaching material

\begin{tabular}{cccccccc}
\hline & & \multicolumn{3}{c}{$\begin{array}{c}\text { Concentrations of } \\
\text { No }\end{array}$} & Parameters $/ \mathrm{kg})$ & \multicolumn{3}{c}{ TCLP $(\mathrm{mg} / \mathrm{kg})$} & Methods \\
\cline { 3 - 6 } & & $\mathrm{RMA}-1$ & $\mathrm{RMA}-2$ & $\mathrm{RMA}-1$ & $\mathrm{RMA}-2$ & $\begin{array}{c}\text { Max. US } \\
\text { EPA }\end{array}$ \\
\hline 1. & $\mathrm{Cr}$ & 36.6 & 42.4 & $<0.048$ & $<0.048$ & 5 & AAS \\
2. & $\mathrm{Ba}$ & 30.6 & 185 & 0.17 & 0,61 & 1 & AAS \\
3. & $\mathrm{Cu}$ & 24.1 & 32.57 & $<0.027$ & $<0.027$ & 10 & AAS \\
4. & $\mathrm{Zn}$ & 25.4 & 82.4 & $<0.01$ & $<0.01$ & 50 & AAS \\
5. & $\mathrm{Ag}$ & 4.14 & $\mathrm{nd}$ & 0,017 & 0,009 & 5 & AAS \\
6. & $\mathrm{As}$ & 3.76 & 0.92 & nd & nd & 5 & MP \\
7. & $\mathrm{Hg}$ & 2.34 & 0.04 & 0,001 & $<0.001$ & 0.2 & MA \\
8. & $\mathrm{Se}$ & 2.32 & 0.45 & nd & nd & & MP \\
9. & $\mathrm{~Pb}$ & $<0.038$ & nd & $<0.038$ & $<0.038$ & 5 & AAS \\
10. & $\mathrm{Cd}$ & $<0.006$ & nd & $<0.006$ & $<0.006$ & 1 & AAS \\
\hline
\end{tabular}

Note: MA is Mercury Analyzer

MP is Micro Plasma

Table 5. Radioactivity of some radionuclide in the Indonesian bauxite residue

\begin{tabular}{|c|c|c|c|c|c|}
\hline \multirow[t]{2}{*}{ No. } & \multirow[t]{2}{*}{ Radionuclide } & \multicolumn{2}{|c|}{$\begin{array}{l}\text { Lowest detected concentration } \\
(\mathrm{Bq} / \mathrm{Kg})\end{array}$} & \multicolumn{2}{|c|}{$\begin{array}{l}\text { Radioactivity concentration } \\
(\mathrm{Bg} / \mathrm{kg})\end{array}$} \\
\hline & & RMA-1 & RMA-2 & RMA-1 & RMA-2 \\
\hline 1. & Uranium-238 & U) : 1.66 & U) : 2.85 & $18.70 \pm 3.41$ & $<2.85$ \\
\hline 2. & Lead-210 $\left({ }^{210} \mathrm{~Pb}\right)$ & $\left({ }^{210} \mathrm{~Pb}\right): 0.65$ & $\left({ }^{210} \mathrm{~Pb}\right): 1.12$ & $6.53 \pm 1.24$ & $<1.12$ \\
\hline 3. & Radium-226 ( $\left.{ }^{226} \mathrm{Ra}\right)$ & $\left({ }^{226} \mathrm{Ra}\right): 0.05$ & $\left({ }^{226} \mathrm{Ra}\right): 0.05$ & $21.68 \pm 2.43$ & $16.69 \pm 1.92$ \\
\hline 4. & Radium-228 ( $\left.{ }^{228} \mathrm{Ra}\right)$ & $\left({ }^{228} \mathrm{Ra}\right): 0.04$ & $\left({ }^{228} \mathrm{Ra}\right): 0.08$ & $21.82 \pm 2.42$ & $12.89 \pm 1.70$ \\
\hline 5. & Thorium-228 ( $\left.{ }^{228} \mathrm{Th}\right)$ & $\left({ }^{228} \mathrm{Th}\right): 0.02$ & $\left({ }^{228} \mathrm{Th}\right): 0.05$ & $19.97 \pm 2.11$ & $13.35 \pm 1.57$ \\
\hline 6. & Thorium-230 ( $\left.{ }^{230} \mathrm{Th}\right)$ & $\left({ }^{230} \mathrm{Th}\right): 1.21$ & $\left({ }^{230} \mathrm{Th}\right): 2.17$ & $13.20 \pm 2.42$ & $<2.17$ \\
\hline 7. & Thorium-234 ( $\left.{ }^{234} \mathrm{Th}\right)$ & $\left({ }^{234} \mathrm{Th}\right): 0.12$ & $\left({ }^{234} \mathrm{Th}\right): 0.21$ & $33.47 \pm 4.91$ & $9.62 \pm 1.99$ \\
\hline 8. & Potassium-40 $\left({ }^{40} \mathrm{~K}\right)$ & & $\left({ }^{40} \mathrm{~K}\right): 0.21$ & & $14.88 \pm 2.54$ \\
\hline
\end{tabular}

\section{CONCLUSION AND SUGGESTION}

In the concentration of below $100 \mathrm{ppm}$, some of the heavy metals or other trace metals might be economically worthless while the others could act as the hazardous constituent for the environment. The natural radioactive elements such as ${ }^{238} \mathrm{U},{ }^{210} \mathrm{~Pb}$, ${ }^{226} \mathrm{Ra},{ }^{228} \mathrm{Ra},{ }^{230} \mathrm{Th}$ and ${ }^{234} \mathrm{Th}$ were also detected in the bauxite residue. 
In general, from the environmental point of view, the alumina refinery residue is categorized as a large-volume hazardous waste. If it is modified, it will have beneficial physical and chemical properties. The experimental study on the chemical composition of West Kalimantan bauxite residue showed some characteristics as follows:

- bauxite residue from alumina processing plant was found consisting of mainly $\mathrm{Fe}_{2} \mathrm{O}_{3}, \mathrm{Al}_{2} \mathrm{O}_{3}, \mathrm{SiO}_{2}, \mathrm{Na}_{2} \mathrm{O}, \mathrm{CaO}, \mathrm{TiO}_{2}$, $\mathrm{K}_{2} \mathrm{O}$ and $\mathrm{MgO}$. The high concentration of iron in the residue was predicted easily to recover;

- the residue also contained rare earth elements (REE) and the lanthanide elements which could be potential resources if it can be economically extracted by existing technology. Those are $\mathrm{Ga}, \mathrm{Ce}, \mathrm{Sc}, \mathrm{Pr}, \mathrm{Gd}$, Tb and etc.;

- the residue was also composed by trace elements such as $\mathrm{Cr}, \mathrm{Ba}, \mathrm{Cu}, \mathrm{Zn}, \mathrm{Ag}, \mathrm{As}$, $\mathrm{Hg}$, Se, $\mathrm{Pb}$ and $\mathrm{Cd}$;

- the residue is not characterized as hazardous waste due to the result of its toxicity leaching test. The TCLP results showed that all parameter for heavy metals were below the maximum allowable concentration;

- the environmental risk point of view, other toxicity test should be carried out with another experimental test which could show the detailed toxicity condition of the bauxite residue;

- the problem of large amounts of bauxite residue can be solved by high consumption of this material by considering the concentration of its residual sodium and its radioactivity. Other beneficial uses of the residue depend on the undissolved constituents in the bauxite ores, in this case, residue which are composed mainly of iron minerals such as hematite and goethite.

\section{ACKNOWLEDGEMENT}

The authors would like to acknowledge the RDCMCT for providing research budget, Andika, Arum and all staffs of the laboratory who involved in this experiment.

\section{REFERENCES}

Amalia, D. and Aziz, M. (2011) "Percobaan pendahuluan pembuatan alumina kualitas metalurgi dari bauksit Kalimantan Barat," Jurnal Teknologi Mineral dan Batubara, 7(4), pp. 183191.

Aziz, M. (2012) "Konsep pemanfaatan dan pemrosesan mineral ampas, Studi kasus rencana pemrosesan ampas bauksit Kalimantan Barat," Jurnal Teknologi Mineral dan Batubara, 8(1), pp. 28-35.

Bray, E. L. (2015) Mineral commodity summaries 2016. Virginia. Available at: https://minerals.usgs.gov/minerals/pubs/ mcs/2016/mcs2016.pdf.

Cablik, V. (2007) "Characterization and application of bauxite residue from bauxite processing," Mineral Resources Management, 23(4), pp. 27-38. Available at: https://minpan.krakow.pl/Wydawnictwa/GSM234/c ablik.pdf.

Cooper, M. B. (2005) Naturally occurring radioactive materials (NORM) in Australian industries - Review of current inventories and future generation. Available at: https://www.researchgate.net/publication /237209484_Naturally_Occurring_Radio active_Materials_NORM_in_Australian_I ndustries_-

Review_of_Current_Inventories_and_F uture_Generation.

Deady, E., Mouchos, E., Goodenough, K. and Williamson, B. J. (2015) "Developing alternative resources of rare-earth element in Europe - EURARE and the bauxite residue challenge," in Geophysical Research Abstract Vol. 17. Vienna, Austria: European Geosciences Union General Assembly 2015, pp. 1-2.

Deady, É., Mouchos, E., Goodenough, K., Williamson, B. and Wall, F. (2014) "Rare earth elements in karst bauxites: A novel untapped European resources?," in European Rare Earth Resources Conference. Milos Island: European Rare Earth RESources (ERES), pp. 112. 
Deady, É., Mouchos, E., Goodenough, K., Williamson, B. and Wall, F. (2016) "A review of the potential for rare-earth element resources from European red muds: examples from Seydişehir, Turkey and Parnassus-Giona, Greece," Mineralogical Magazine, 80(1), pp. 4361. doi: 10.1180/minmag.2016.080.052.

Dobra, G., Filipescu, L., Anghelovici, N., Alistarh, V. and Iliev, S. (2015) "Bauxite residue safety disposal and friendly environmental processing permanent care at Vimetco Alum SA Tulcea," in Bauxite Residue Valoration and Best Practices. Leuven, Belgium, pp. 47-52.

Evans, K. (2015) "Successes and challenges in the management and use of bauxite residue," in Bauxite Residue Valoration and Best Practices. Leuven, Belgium, pp. 113-128.

Gow, N. N. and Lozej, G. P. (1993) "Bauxite," Geoscience Canada, 20(1), pp. 9-16.

Grafe, M., Landers, M., Tappero, R., Klauber, C., Hutomo, G., Gan, B., Grabsch, A., Austin, P. and Davies, I. (2010) "Chemistry of trace and heavy metals in bauxite residues (bauxite residue) from Western Australia," in Gilkes, R., Prakongkep, N., Gilkes, R., and Prakongkep, N. (eds.) 19th World Congress of Soil Science, Soil Solutions for a Changing World. Brisbane, Australia: International Union of Soil Sciences, pp. 39-42.

Gu, H., Wang, N. and Liu, S. (2012) "Characterization of bayer bauxite residue from Guizhou China," Minerals \& Metallurgical Processing, 29(3), pp. 169-171.

Hai, L. D., Khai, N. M., Quy, T. Van and Huan, N. X. (2014) "Material composition and properties of bauxite residue coming from alumina processing plant Tanrai, Lamdong, Vietnam," International Journal of Research In Earth \& Environmental Sciences, 1(6), pp. 1-7.

Head of Agency of Nuclear Energy Supervision (2009) Intervention of exposure from technologically enhanced naturally occurring radioactive material. Indonesia. Available at: http://jdih.bapeten.go.id/index.php/site/d okview/id/123.

Head of Agency of Nuclear Energy Supervision (2013) Radiation safety on the safekeeping or storage of the technologically enhanced naturally occurring radioactive material. Indonesia. Available at: http://jdih.bapeten.go.id/index.php/site/d okview/id/349.

Ibrahiem, N., Abd El Maksoud, T., El Ezaby, B. Nada, A. and Abu Zeid, H. (1999) "Natural radioactivity in Egyptian and industrially used Australian," in International Symposium on Restoration of Environments with Radioactive Residues. IAEA, pp. 23-26.

Kuo, C. S. (2015) "The mineral industry of Indonesia," in 2012 Minerals Yearbook. U.S. Department of the Interior, p. 11.111.9.

Li, L. Y. (1998) "Properties of red mud tailings produced under varying process conditions," Journal of Environmental Engineering, 124(3), pp. 254-264. doi: 10.1061/(ASCE)07339372(1998)124:3(254).

Miraza, T. (2011) "The Indonesian Alumina Project Development," in Asian Bauxite and Alumina Conference, pp. 1-4.

Palmer, S., Frost, R. and Nguyen, T. (2009) "Hydrotalcites and their role in coordination of anions in Bayer liquors: Anion binding in layered double hydroxides," Coordination Chemistry Reviews, 253(1-2), pp. 250-267. doi: 10.1016/j.ccr.2008.01.012.

Patel, S. and Pal, B. K. (2015) "Current status of an industrial waste: Red mud an overview," IJLTEMAS, 4(8), pp. 1-16.

Rai, S., Wasewar, K. L., Mukhopadhyay, J., Yoo, C. K. and Uslu, H. (2012) "Neutralization and utilization of red mud for its better waste management," Arch. Environ. Sci., 6, pp. 13-33.

Ranveer, A. C. (2015) "Review paper on bauxite residue characteristics, disposal and utilization," IJIERT, 2(4), pp. 1-7.

Schwarz, M. and Lalk, V. (2012) "Possibilities of Exploitation of Bauxite Residue from Alumina Production," in Recent Researches in Metallurgical Engineering - From Extraction to Forming. InTech, p. 21. doi: $10.5772 / 37644$.

Suseno, T. (2010) "Analisis Nilai Sumber Daya Bijih Bauksit, Nikel dan Emas PT. Antam Tbk.," Jurnal Teknologi Mineral dan Batubara, 6(4), pp. 174-182. 
Tóth, A. K., Gonda, N., Fekete, Z., Tóth, M., Székely, I. and Zákányi, B. (2014) "Physical and chemical characterization of red mud in terms of its environmental effects," Geosciences and Engineering, 3(5), pp. 129-137.

Tsamo, C., Parfait, Z. A., Kamga, R., P.D., B. B. and Bikié-Mbah, J. B. (2014) "Preparation and characterization of bauxite residue derived from MinimMartap (Cameroon) bauxite," IJRCE, 4(2), pp. 153-160.

Tsurikov, N. (1999) TENORM legislation - theory and practice (a Review of relevant issues), IAEA. Available at:
http://www.iaea.org/inis/collection/NCLC ollectionStore/_Public/33/016/33016250. pdf (Accessed: March 24, 2016).

Utasi, A., Sebestyén, V., Németh, J., Juzsakova, T., Dióssy, L., Domokos, E., Robu, B., Rédey, A., Ráduly, I. and Ráduly, L. (2014) "Advanced environmental impact assessment: quantitative method for bauxite residue disposal," Environmental Engineering and Management Journal, 13(9), pp. 2295-2300. 